\title{
Accountability: Efforts to Prevent Rush Money at Village Credit Institutions
}

\section{Ni Wayan Novi Budiasni ${ }^{*}$, Ni Made Sri Ayuni²}

1,2 Sekolah Tinggi Ilmu Ekonomi Satya Dharma, Indonesia

\section{ART ICLE IN F O}

Article history:

Received April 08, 2021

Revised April 03, 2021

Accepted May 02, 2021

Available online May 25, 2021

Keywords:

Internal Control System,

Presentation of Financial

Statements, Accountability

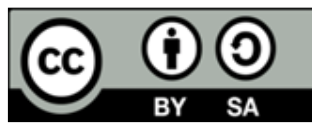

This is an open access article under the CC BY-SA license.

Copyright $(2021$ by Author. Published by Universitas Pendidikan Ganesha.

\begin{abstract}
A B S T R A C T
Ensuring the confidence of customers and other stakeholders, LPD requires an internal control system, presentation of financial statements and accountability. The purpose of this research is to know the implications of the internal control system and the presentation of financial statements to accountability. This study used quantitative method, population of 149 LPD that is still operating and selected 60 LPD samples in Buleleng Regency. Questionnaire as an instrument to collect research data. The analysis technique used is SEM (Structural Equation Modelling) with PLS (Partial Least Square) method. Based on the first hypothesis it appears that the relationship between internal control system variables and accountability of parameter coefficients 0.364 with a statistical $t$ value of 4.056 greater than the table $t$ value of $1,960(4,056>1,960)$. Similarly, the second hypothetical relationship between the presentation of financial statements has a parameter coefficient value of 0.525 with a statistical $t$ value of 6.362 greater than the table $t$ of $1,960(6,362>1,960)$. Based on the results of the study, it can be concluded that the internal control system is positively related to accountability, and the presentation of financial statements relates positively to accountability.
\end{abstract}

\section{INTRODUCTION}

The financial services industry (IJK) has not escaped the impact of the covid-19 pandemic, including the Village Credit Institute (LPD) in Bali. There has been a decrease in profit at the Village Credit Institution (LPD) worth $27.3 \%$ or 398.3 billion. In addition, non-current credit also adds to the case of decreased lpd performance, one of which is LPD Anturan Traditional Village, Buleleng, Bali. Anturan LPD congestion occurs due to bad credit of 150 billion. In addition to bad credit, the problem that arises today is rush money (massive withdrawal of funds) by customers. During the pandemic, rush money conditions occur due to unstable economic conditions that trigger a weakening of public trust as customers. The occurrence of rush money causes damage to the most important joints of banking, thus triggering default by the bank concerned. Bad credit, rush money, and declining profits have an impact on LPD financial reporting. Financial reporting conveys financial information to stakeholders related to the LPD situation. Although lpd's financial condition is shaken due to the unstable economic situation, financial reporting should still be presented accountably, which is in accordance with applicable accounting standards and reflects the actual financial condition of LPD. Accountability should be able to ensure the quality of information provided. The most important thing is that accountability is a reflection of the success and failure of an institution's financial management system (Saputra et al., 2018; Sari et al., 2020).

Before the realization of accountability, LPD requires an internal control system that monitors every activity continuously and is carried out by the leadership and all employees so that the public or customers are confident that LPD is able to achieve its objectives effectively and efficiently (Arsini et al., 2018; Dewi \& Ernawatiningsih, 2019). Through the internal control system will have an impact on performance results, lpd financial position when reporting financial to lpd accountability. The importance of internal control systems to prevent non-performing loans from misappropriation. Similarly, internal control systems are important to maintain the efficiency of the company's operational activities (Amir \& Nurfika, 2018; Sari et al., 2020). Through the internal control system, LPD is able to create effective and efficient operational activities during the Covid-19 Pandemic that have an impact on lpd's work. The most important thing is that with a good internal control system, stakeholders become more confident with the accountability produced by LPD (Handayani et al., 2020). Because, customers become more confident about the reliability of financial reporting information submitted (Kepramareni \& Pradnyawati, 2021; Sari 
et al., 2020). In order to create guaranteed accountability, a complete presentation of financial reporting is required. Financial statements have a very important purpose, namely as a liaison of the company with interested parties, which indicates the health condition of the company (Hardiningsih et al., 2019; Hery, 2013). In order for the purpose of the preparation and presentation of financial statements to be achieved, the effort that can be made is to prepare financial statements in accordance with the principles on time and in accordance with accounting standards (Ghozali, 2018; Kurniawan \& Rahayu, 2019). The better the presentation of financial statements, the clearer the financial information submitted.

Based on the above explanation, that the internal control system and presentation of financial statements are stated as an important part for the creation of accountable LPD operations. Accountability in the condition of the Covid 19 pandemic is considered increasingly important to be maintained in order to maintain public confidence as customers. A good internal control system and the presentation of quality financial statements will support the achievement of accountability. The same was said by previous study, who stated that the internal control system and presentation of financial statements significantly affect accountability (Hardiningsih et al., 2019). However, the internal control system and the presentation of financial statements have no effect on accountability (Kurniawan \& Rahayu, 2019; Ledo \& Ayem, 2017). Similarly, other previous study states that the presentation of financial statements has no significant influence on accountability, but the internal control system has a significant influence on accountability (Sari et al., 2020). The inconsistency of previous research results and the condition of Pademi Covid 19 which led to a decrease in LPD assets in Bali up to 3\% per year in 2020 due to the impact of Covid 19, became the motivation of the author to review the relationship between the internal control system and the presentation of LPD financial statements with LPD accountability in Buleleng Regency, Bali. The purpose of this research is to know the implications of the internal control system and the presentation of financial statements to accountability.

\section{METHODS}

The research method used is quantitative method, which is to explore causality between variables. This study examined the causal relationship between variables of internal control system, presentation of financial statements and accountability of LPD in Buleleng Regency. During the covid-19 pandemic situation, it becomes a must for LPD to maintain the confidence of customers and other stakeholders to prevent rush money. One of the efforts that can be taken is to implement an internal control system and the presentation of accountable financial statements. The research design as presented in Figure 1.

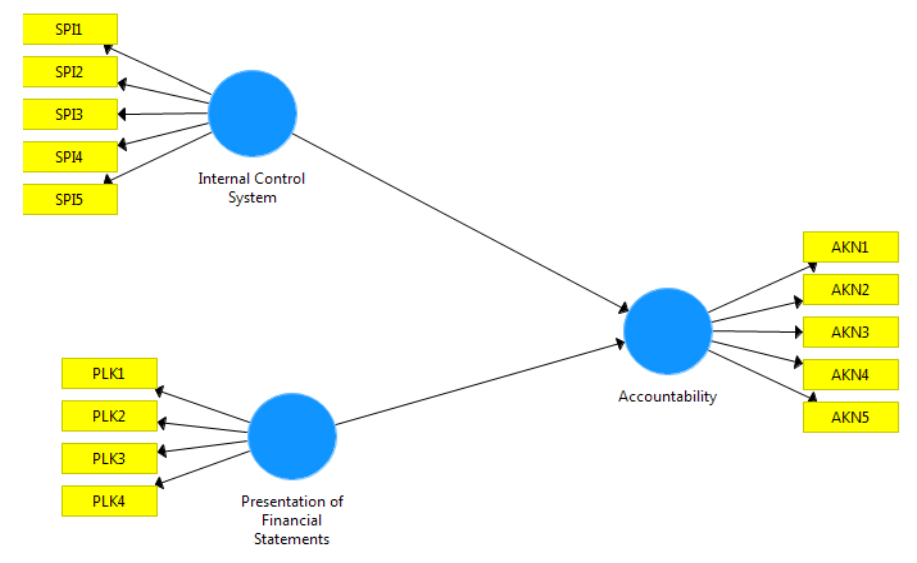

Figure 1. Research Design

This research targeted the Village Credit Institute in Buleleng Regency. LPD In Buleleng Regency became the target of research related to internal control system and presentation of interesting financial statements due to the covid-19 pandemic situation that triggered the decline in LPD assets to the decrease in profit and the existence of lpd cases of traffic jams. There are 149 LPDs that still operate as research populations and 60 LPD as research samples determined by slovin formula. Questionnaires with a likert interval scale of 1-5 were disseminated to LPD as a research instrument to collect research data. Test the reliability of questionnaire answers using Cronbach Alpha and validity test by comparing correlation values ( $r$ count) with t-table. Data analysis techniques using SEM (Structural Equation Modeling) analysis 
using PLS (Partial Least Square) method (Ghozali, 2018). Stages of data analysis namely: The first stage is to evaluate the measurement model (outer model). Test validity and reliability by performing Convergent Validity, Discriminant Validity Composite Reliability, Cronbach's Alpha and AVE. Formative indicators are tested with weight significance and multicolonrity. The second stage is to evaluate the structural model (inner model). The evaluation in this model will be seen from the coefficient of determination (R2), predictive relevance (Q2), goodness of git index (GoF). Hypothesis testing is seen from t-statistical values and probability values. Hypothesis testing uses statistical values, so for alpha $5 \%$ the statistical $t$ value used is 1.96 .

\section{RESULTS AND DISCUSSIONS}

\section{Results}

Accountability as an endogenous variable consists of 5 indicators, namely, the process of making a decision made in writing (AKN1), policies available to citizens in need (AKN2), decisions taken in compliance with ethical standards and applicable values (AKN3), decisions taken in compliance with the principles of correct administration (AKN4), and clarity of the objectives of policies made and communicated (AKN5). While other variables are exogenous variables, namely internal control system and presentation of financial statements. The internal control system indicator consists of 5 indicators, namely environmental control (SPI1), risk assessment (SPI2), control activities (SPI3), information and communication (SPI4), internal control monitoring (SPI5). The presentation variable of financial statements consists of 4 indicators, including relevant (PLK1), reliable (PLK2), comparable (PLK3), and understandable (PLK4).

\section{Outer Model or Measurement Model}

Constructs can be declared to have high reliability if the composite reliability value is above 0.70 , the Cronbachs Alpha value is above 0.60, the rho_A above 0.70, and the AVE is above 0.50 (Ghozali, 2018). Table 1 presented the values Cronbachs Alpha, rho_A, Composite Reliability and Average Variance Extracted (AVE) for all variables.

Table 1. Construct Reliability and Validity

\begin{tabular}{lcccc}
\hline & $\begin{array}{c}\text { Cronbach's } \\
\text { Alpha }\end{array}$ & rho_A & $\begin{array}{c}\text { Composite } \\
\text { Reliability }\end{array}$ & $\begin{array}{c}\text { Average Variance } \\
\text { Extracted (AVE) }\end{array}$ \\
\hline Accountability & 0,852 & 0,869 & 0,892 & 0,622 \\
Internal Control System & 0,860 & 0,889 & 0,903 & 0,701 \\
Presentation of Financial & 0,905 & 0,915 & 0,930 & 0,726 \\
Statements & & & 0 \\
\hline
\end{tabular}

Table 1 shows that all constructs in this study resulted in a Composite Reliability value above 0.70 and a Cronbach's Alpha value above 0.60 . The lowest value for Composite Reliability on the accountability construct is 0.892 and Cronbach's Alpha on the accountability construct reaches a value of 0.852 . It can be concluded that the constructs in this study are reliable. Furthermore the AVE value is above 0.5 for all constructs on the research model. The lowest AVE value of 0.622 on the accountability construct, so it can be concluded that the construct in this study is valid. The rho_A value is above 0.70 for all constructs. Measurements of the magnitude of the correlation between constructs and latent variables can also be seen in the path chart in Figure 2. Based on Figure 2, all variable indicators have a loading value of more than 0.5 which indicates that all indicators are valid.

\section{Structural Model Testing (Inner Model)}

Structural model testing was conducted to determine the relationship between latent constructs in the research model. The inner model assessment can be seen from $\mathrm{R}$ Square for all dependent latent variables (Ghozali, 2018). Table 2 presents about R Square.

Table 2. R-Square Value

\begin{tabular}{ccc}
\hline & R Square & R Square Adjusted \\
\hline Accountability & 0,719 & 0,709 \\
\hline
\end{tabular}


There is a range of R Square values that are 0.67 (strong), 0.33 (medium) and 0.19 (weak) (Chin, 1998). When viewed in Table 2 , the value of $R$ Square reaches 0.719 which is $71.9 \%$. So the value of $71.9 \%$ of the accountability construct has been explained by the variables of the internal control system construct and the presentation of financial statements. Only $28.1 \%$ is described by other variables.

\section{Hypothesis Testing}

The main basis used to test hypotheses is the value contained in the output result for the inner weight. Table 3 describes the results of hypothesis testing.

Table 3. Result for Inner Weight

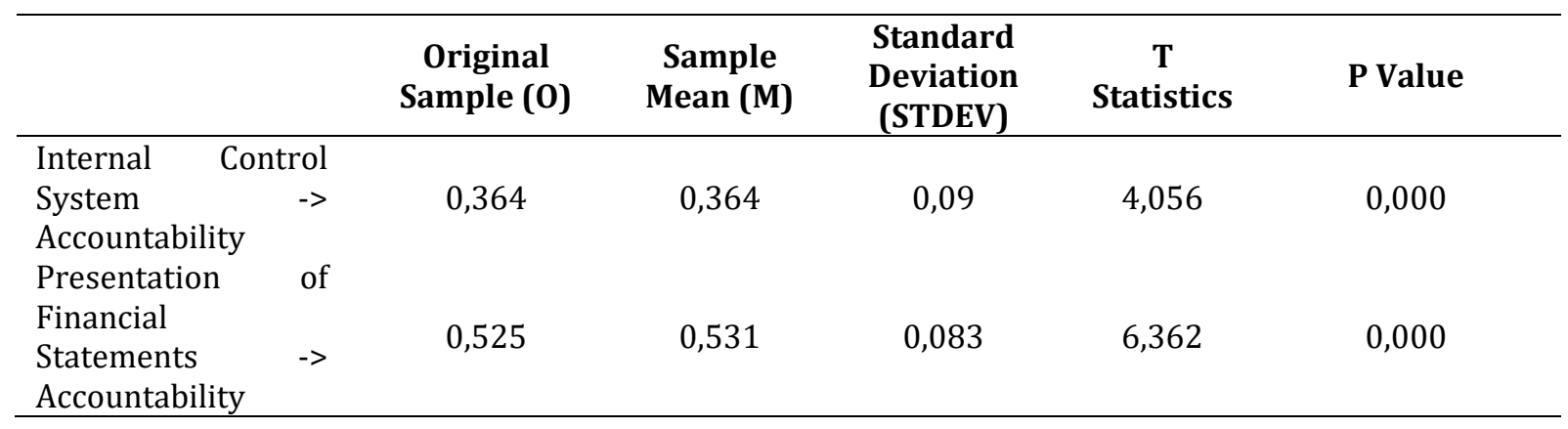

Based on Table 3, it can be seen that the relationship between internal control system and accountability has an influence. It is indicated by a parameter coefficient value of 0.364 with a statistical $t$ value of 4.056 greater than the table $t$ value of $1,960(4,056>1,960)$. Similarly, the relationship between the presentation of financial statements that have a parameter coefficient value of 0.525 with a statistical $t$ value of 6.362 greater than the table $t 1,960(6,362>1,960)$.

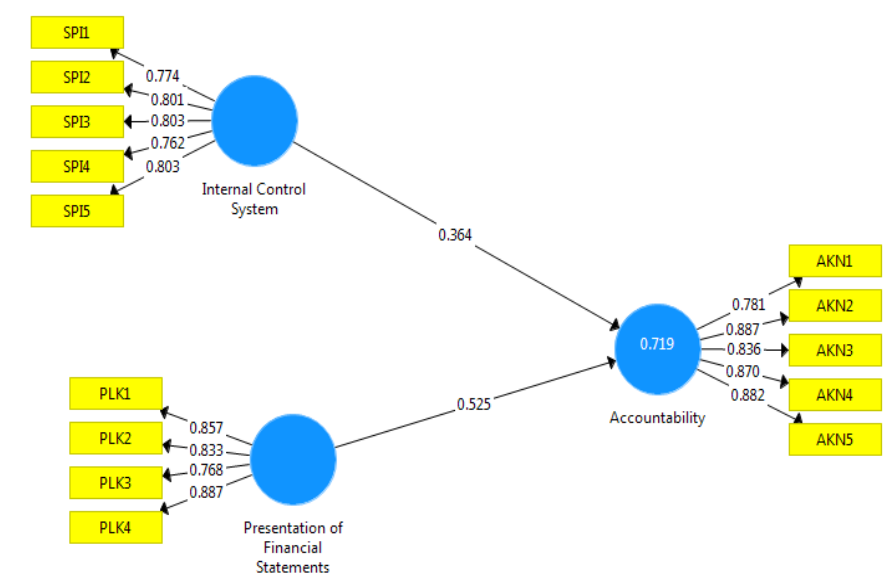

Figure 2. Algorithem

\section{Discussion \\ The Impact of Internal Control Systems on Accountability}

Based on the results of the study, the internal control system has a significant positive effect on accountability. This shows that the internal control system has an important role in an organization including LPD in Buleleng Regency in realizing accountability. Internal control system has an important purpose to ensure a company or LPD operates in accordance with the prevailing laws and regulations and does not violate the rules. Internal control systems include coordinated methods and policies within the company to secure the company's wealth, to test the accuracy, accuracy and reliability of accounting records or data and to encourage the adhered to management policies. Adherence to management policies shows good operations. Because, when an organization including LPD In Buleleng Regency that has been given trust should put the interests of the organization and stakeholders LPD. The same was said by previous study, who stated that putting the interests of the organization first is more important and should override other interests in order to achieve the main objectives of the organization (Pramesti et al., 
2018). Thus, if the internal control system of LPD is done well, then the objectives of lpd management accountably can be realized.

The results of this study are supported by previous research, which stated that the internal control system affects accountability (Sari et al., 2020). The same was also stated that the improved internal control system, the better accountability is achieved. If the internal control system is implemented thoroughly and integrally, it is certainly able to create good management accountability (Azizah et al., 2015; Hardiningsih et al., 2019). The internal control system has a significant positive effect on accountability (Kepramareni \& Pradnyawati, 2021; Widyatama et al., 2017). Based on these results, the internal control system becomes one of the important factors that can have implications on management decision making and accountability and transparency of an organization. An inestimable internal control system causes problems in financial management activities of under accountable financial reporting (Artini \& Putra, 2020). Effective financial management will be realized if LPD is able to create, implement, and maintain an internal control system. Implementation of a good internal control system, will provide adequate confidence in the achievement of objectives, and asset security, to the prevention of misappropriation in the LPD environment. The belief is formed because in the internal control system, LPD supervisors will monitor the operational suitability of LPD management with the established rules and produce good accountability (Manullang \& Abdullah, 2019).

\section{Effect of Financial Statement Presentation on Accountability}

The results showed that the presentation of financial statements positively affected accountability. The results of this study were supported by several previous studies, who found that the presentation of financial statements affected accountability (Guasmin \& Febrianti, 2019; Hardiningsih et al., 2019; Kurniawan \& Rahayu, 2019). This shows that the better the presentation of financial statements will certainly clarify LPD financial reporting because all financial transactions are conducted in accordance with existing regulations and presented completely and honestly in the financial statements. Previously, the presentation of financial statements that are prepared in full, can be completed on time, provide information that can correct financial activities in the past, honest transactions that should be presented in financial statements, can be used as a benchmark in the preparation of the next year's budget, and can be understood by users because it is stated in the form and terms that are adjusted to the limits of the user's ability, the accountability of regional financial management tends to be good (Darmada et al., 2016; Lewis-Beck et al., 2012). These criteria are evidence that the presentation of financial statements is essential for accountability.

Financial statements are not only for accountability but also play a role to help users in decision making, both external and internal users (Priharjanto, 2020; Sulistiani et al., 2017). Financial statements also provide information to internal users in decision making, in this case management. Management should be able to use financial information in carrying out management functions that include planning, management, and control. No less important was also stated that proper financial statements have become a key component where accountability is expected and can be demonstrated (Darmawan et al., 2015; Ridzal, 2020). Assessment of organizational performance can be done by stakeholders through financial statements. The financial statements present information such as assets, liabilities, equity, income and expenses including profits and losses, as well as contributions and distributions to owners who in this case are Pakraman village owners. The presentation of financial statements must be reasonably in accordance with accounting policies, changes in accounting estimates and errors. In addition, accounting presentation should be with relevant information, reliable and easy to understand. Management needs relevant information, as well as LPD service connoisseurs of course in need of quality information (Noviyana \& Pratolo, 2018). Similarly, management in an LPD, community or traditional village manners as service connoisseurs as well as LPD owners are certainly in need of reliable information.

\section{CONCLUSION}

The results of sem (Structural Equation Modeling) analysis using PLS (Partial Least Square) method are known that the internal control system and presentation of financial statements have a significant positive effect on accountability in Buleleng Regency LPD. This shows that the internal control system and financial presentation have an important role to improve the quality of accountability in LPD in Buleleng Regency. Internal control system as a control tool in overseeing LPD operations becomes an important factor in producing accountable management in LPD. Similarly, the presentation of financial statements, which presents financial information to users. Financial statements that are presented well are financial statements that are in accordance with the provisions, so that it can be declared an 
accountable report. This is very important, considering the financial statements as the basis for lpd management decision making. The quality of LPD accountability is important to be improved in order to maintain customer confidence and confidence in times of unstable economic conditions due to the impact of the covid-19 pandemic. R Square's results showed that $28.1 \%$ of accountability variables were influenced by variables other than the internal control system and the presentation of financial statements. Further research is expected to add other variables to maximize the results of research, and contribute more to LPD in Buleleng Regency.

\section{REFERENCES}

Amir, \& Nurfika, A. I. (2018). Sistem Pengendalian Intern Dalam Upaya Mencegah Terjadinta Kredit Macet Pada PT Bank Rakyat Indonesia (Persero) Tbk Kantor Cabang Sinjai. Akmen Jurnal Ilmiah, 15(2), 294-309. https://doi.org/10.37476/akmen.v15i2.302.

Arsini, K., Yuniarta, G. A., \& Dewi, P. E. D. M. (2018). Pengaruh Sistem Pengendalian Internal, Pemanfaatan Teknologi Informasi, dan Tingkat Profitabilitas terhadap Ketepatan Waktu Pelaporan Laporan Keuangan LPD di Kecamatan Banjar, Seririt, Busungbiu, dan Gerokgak. JIMAT (Jurnal Ilmiah Mahasiswa Akuntansi) Undiksha, 8(2). https://doi.org/10.23887/jimat.v8i2.13481.

Artini, N. L. W., \& Putra, I. P. D. S. (2020). Pengaruh Penyajian Laporan Keuangan Daerah, Aksesibilitas Laporan Keuangan Dan Sistem Pengendalian Intern Terhadap Akuntabilitas Pengelolaan Keuangan Daerah. Hita Akuntansi Dan Keuangan, 1(2), 188-218. https://ejournal.unhi.ac.id/index.php/HAK/article/view/978.

Azizah, N., Junaidi, \& Setiawan, A. R. (2015). Penyajian Laporan Keuangan, Aksesibilitas Laporan Keuangan, dan Sistem Pengendalian Internal Pemerintah sebagai Determinan Transparansi dan Akuntabilitas Pengelolaan Keuangan Daerah. Journal of Research and Applications: Accounting and Management, 1(2), 111. https://doi.org/10.18382/jraam.v1i2.18.

Chin, W. W. (1998). The Partial Least Squares Approach to Structural Equation Modeling. Modern Methods for Business Research. Modern Methods for Business Research, 295(2), 295-336. https://psycnet.apa.org/record/1998-07269-010.

Darmada, D. K., Atmadja, A. T., \& Sinarwati, N. K. (2016). Kearifan Lokal Pade Gelahang dalam Mewujudkan Integrasi Akuntabilitas Pengelolaan Keuangan Organisasi Subak. Jurnal Akuntansi Multiparadigma, 7(1), 51-60. https://doi.org/10.18202/jamal.2016.04.7004.

Darmawan, I. G. S., Atmadja, A. T., \& Herawati, N. T. (2015). Analisis Akuntabilitas Pengelolaan Keuangan "Pura Kahyangan Tiga" Di Desa Adat Sanggalangit Kecamatan Gerokgak Kabupaten Buleleng Provinsi Bali. JIMAT (Jurnal Ilmiah Mahasiswa Akuntansi) Undiksha, 3(1). https://doi.org/10.23887/jimat.v3i1.6208.

Dewi, N. P. S., \& Ernawatiningsih, N. P. L. (2019). Analisis Determinan Kualitas Laporan Keuangan Lembaga Perkreditan Desa (LPD) di Kota Denpasar. Jesya (Jurnal Ekonomi Dan Ekonomi Syariah), 2(1), 148-157. https://doi.org/10.36778/jesya.v2i1.31.

Ghozali, I. (2018). Aplikasi Analisis Multivariate dengan Program IBM SPSS 25 (9th editio). Badan Penerbit Universitas Diponegoro.

Guasmin, \& Febrianti, D. (2019). Pengaruh Penyajian Laporan Keuangan Daerah Dan Aksesibilitas Laporan Keuangan Daerah Terhadap Transparansi Dan Akuntabilitas Pengelolaan Keuangan. Sinar Manajemen, 6(2), 129-134. https://doi.org/10.31934/jsm.v6i2.863.

Handayani, N. K. P., Suryandari, N. N. A., \& Putra, G. B. B. (2020). Pengaruh Prinsip-Prinsip Good Corporate Governance Terhadap Kinerja Lembaga Perkreditan Desa (Lpd) Di Kecamatan Rendang Kabupaten Karangasem. Kumpulan Hasil Riset Mahasiswa Akuntansi (KHARISMA), 2(1), 11-21. http://e-journal.unmas.ac.id/index.php/kharisma/article/view/729.

Hardiningsih, P., O., R. M., Srimindarti, C., \& Kristiana, I. (2019). Determinan Akuntabilitas Pengelolaan Keuangan Daerah (Studi Kasus pada Pemerintah Daerah Kabupaten Pemalang). AKTSAR: Jurnal Akuntansi Syariah, 2(1), 21. https://doi.org/10.21043/aktsar.v2i1.4963.

Hery, S. (2013). Akuntansi Jasa dan Dagang. Gava Media.

Kepramareni, P., \& Pradnyawati, S. O. (2021). The Effect of Accountability, Responsibility, Independence, and Fairness on the Performance of Klungkung LPDs. Asia Pacific Journal of Management and Education (APJME), 4(2), 65-73. https://doi.org/10.32535/apjme.v4i2.1143.

Kurniawan, D., \& Rahayu, S. (2019). The Effect Of The Presentation Of Financial Statment And Accessibility Financial Statment On Regional Financial Management Accountability (Case Study in Mataram City Regional Secre). Management, 6(1), 705-714. https://openlibrarypublications.telkomuniversity.ac.id/index.php/management/article/view/87 43. 
Ledo, D., \& Ayem, S. (2017). Pengaruh Aspek-Aspek Manajemen Keuangan Daerah Terhadap Transparansi Pengelolaan Keuangan Daerah. Kajian Bisnis STIE Widya Wiwaha, 25(2), 161-175. https://doi.org/10.32477/jkb.v25i2.236.

Lewis-Beck, M., Bryman, A., \& Futing Liao, T. (2012). Purposive Sampling. The SAGE Encyclopedia of Social Science Research Methods, 1-14. https://doi.org/10.4135/9781412950589.n774.

Manullang, S. B., \& Abdullah, S. (2019). Pengaruh Pengendalian Internal, Kejelasan Anggaran dan Pergantian Kepala SKPD terhadap Akuntabilitas Kinerja. Jurnal Ilmiah Mahasiswa Ekonomi Akuntansi (JIMEKA), 4(1), 62-73. http://www.jim.unsyiah.ac.id/EKA/article/view/8764.

Noviyana, R. A., \& Pratolo, S. (2018). Pengaruh Sistem Pengendalian Intern Dan Motivasi Kerja Terhadap Kinerja Instansi Pemerintah Dengan Akuntabilitas Publik Sebagai Variabel Intervening: Studi pada Organisasi Perangkat Daerah Kabupaten Klaten. Reviu Akuntansi Dan Bisnis Indonesia, 2(2), 129-143. https://doi.org/10.18196/rab.020227.

Pramesti, A., Riyandini, E. C., \& Pesudo, D. A. A. (2018). Akuntabilitas Dan Pengendalian Internal Pada Organisasi Nirlaba (Studi Pada Gbi Ambarawa). Behavioral Accounting Journal, 1(2), 176-192. https://doi.org/10.33005/baj.v1i2.32.

Priharjanto, A. N. A. (2020). Pengaruh Kualitas Laporan Keuangan, Kapasitas Sumber Daya Manusia, dan Aksesibilitas terhadap Pemanfaatan Laporan Keuangan. Jurnal Ilmiah Akuntansi Kesatuan, 13(1), 39-53. https://doi.org/10.35448/jrat.v13i1.7548.

Ridzal, N. A. (2020). Pengaruh Kualitas Laporan Keuangan Terhadap Akuntabilitas Kinerja Pada Badan Pengelolaan Keuangan Dan Aset Daerah (Bpkad) Kabupaten Buton. Financial: Jurnal Akuntansi, 6(1), 87-97. https://doi.org/10.37403/financial.v6i1.135.

Saputra, K. A. K., Anggiriawan, P. B., \& Sutapa, I. N. (2018). Akuntabilitas Pengelolaan Keuangan Desa Dalam Perspektif Budaya Tri Hita Karana. Jurnal Riset Akuntansi Dan Bisnis Airlangga, 3(1). https://doi.org/10.31093/jraba.v3i1.90.

Sari, R. P., Mulyani, C. S., \& Budiarto, D. S. (2020). Pentingnya Pengendalian Internal Untuk Meningkatkan Transparansi Dan Akuntabilitas Pengelolaan Keuangan Daerah. Jurnal Riset Akuntansi Mercu Buana, 6(1), 1. https://doi.org/10.26486/jramb.v6i1.697.

Sulistiani, L. P. D., Atmadja, A. T., SE, A., Herawati, N. T., \& AK, S. (2017). Transparansi dan Akuntabilitas Pengelolaan Dana Punia di Dadia Prebali, Desa Gobleg, Kecamatan Banjar, Kabupaten Buleleng. JIMAT (Jurnal Ilmiah Mahasiswa Akuntansi) Undiksha, 8(2). https://doi.org/10.23887/jimat.v8i2.10747.

Widyatama, A., Novita, L., \& Diarespati, D. (2017). Pengaruh Kompetensi Dan Sistem Pengendalian Internal Terhadap Akuntabilitas Pemerintah Desa Dalam Mengelola Alokasi Dana Desa (Add). Berkala Akuntansi Dan Keuangan Indonesia, 2(2), 1-20. https://doi.org/10.20473/baki.v2i2.4762. 